\title{
ECOLOGICAL ASPECTS OF THE ANTIMICROBIAL RESISTANCE IN BACTERIA OF IMPORTANCE TO HUMAN INFECTIONS
}

\author{
Frederico de Meirelles-Pereira ${ }^{1 *}$; Angela de Meirelles Santos Pereira ${ }^{2}$; Márcio Cataldo Gomes da Silva ${ }^{3}$; \\ Verônica Dias Gonçalves ${ }^{3}$; Paulo Roberto Brum ${ }^{1}$; Eduardo Almeida Ribeiro de Castro²; Alexandre Adler Pereira ${ }^{3}$; \\ Francisco de Assis Esteves ${ }^{1}$; José Augusto Adler Pereira ${ }^{3}$

\begin{abstract}
${ }^{1}$ Laboratório de Limnologia, Departamento de Ecologia, Instituto de Biologia, Centro de Ciências da Saúde, Universidade Federal do Rio de Janeiro, Rio de Janeiro, RJ, Brasil. ²Departamento de Patologia e Laboratórios, Faculdade de Ciências Médicas, Universidade Estadual do Rio de Janeiro, Rio de Janeiro, RJ, Brasil. ${ }^{3}$ Hospital Universitário Pedro Ernesto, Universidade Estadual do Rio de Janeiro, Rio de Janeiro, RJ, Brasil.
\end{abstract}

Submitted: November 13, 2001; Returned to authors for corrections: June 17, 2002; Approved: September 03, 2002

\begin{abstract}
In view of the intimate relationship of humans with coastal lagoons (used for recreation, tourism, water supply, etc.), the discharge of domestic effluents may lead to the establishment of routes of dissemination of pathogenic microorganisms, including microorganisms carrying genes for resistance to antimicrobials, through the surrounding human communities. The objective of the present investigation was to relate the presence of antimicrobial-resistant bacteria to the environmental characteristics of three coastal lagoons, comparing the results with those from hospital sewage. Of the lagoons evaluated, two (Geribá and Imboassica) receive domestic sewage discharge, and the other (Cabiúnas) is still in a natural state. We isolated in a culture medium containing $321 / 4 \mu \mathrm{g} / \mathrm{ml}$ of Cephalothin, fecal coliforms (E. coli), non-fecal coliforms (Klebsiella, Enterobacter, Serratia, and Citrobacter), non-glucose-fermenting Gram-negative bacilli, and Aeromonas sp. In cultures from the hospital drain we found strains showing numerous markers for resistance to most of the 11 antimicrobials tested. On the other hand, in cultures from Cabiúnas and Imboassica lagoons, we found strains showing resistance only to antibiotics frequently observed in non-selective situations (considered as "common" markers). The capacity for dilution in the ecosystem, and salinity appeared related with the occurrence of multi-resistant bacterial strains. The intensity of recent fecal contamination was not shown to be associated with the numbers and types of markers found.
\end{abstract}

Key words: bacterial resistance, eutrophication, sanitary microbiology, environmental microbiology

\section{INTRODUCTION}

The use of bodies of water as receptacles for organic effluents has increased with population growth, aggravating the decline of sanitary conditions in diverse human communities. Discharge of organic effluents into water reservoirs, as well as promoting artificial eutrophication, allows them to be contaminated by pathogenic microbes (10), including carriers of genes for resistance to various antimicrobials (antibiotics and chemotherapeutics). These environments can come to be important sites of human contamination by pathogens that are resistant and multi-resistant to antibiotics.

Bacterial resistance to antimicrobials is a growing medical problem worldwide, generated by selection processes following the massive use of antibiotics. The occurrence of strongly selective environments for antimicrobials such as hospitals, industries, and veterinary activities (where large quantities of antimicrobials are used to promote growth and to prevent and

\footnotetext{
* Corresponding author. Mailing address: Laboratório de Limnologia, Departamento de Ecologia, Instituto de Biologia - CCS - UFRJ, Bloco A, Ilha do Fundão, Caixa Postal 68020. 21941-540. Rio de Janeiro, RJ, Brasil. Telephone/Fax: (+5521) 270-4950. E-mail: fred@biologia.ufrj.br
} 
treat infections) leads to an increase in the frequency of resistance bacterial genes. Degraded sanitation in communities may lead to the establishment of routes for dissemination of microorganisms $(19,22)$ and genetic elements such as plasmids, which can amplify the problem by contributing to the increase of multi-resistant bacteria.

Some microorganisms important in human infection such as the Gram-negative bacilli (GNB), including enterobacteria such as Enterobacter sp., and other GNBs such as the non-glucose fermentors, for example $P$. aeruginosa, may persist for long periods in the environment. The fecal coliforms (E. coli) resistance in extra-intestinal conditions is lower compared to the intestinal tract, so their presence can be taken to indicate recent fecal contamination generated by humans or other warmblooded animals (16). Other enterobacteria, including non-fecal coliforms, and other groups of GNBs (non-fermentors and nutritionally undemanding groups) in addition to the enterococci (especially important agents of hospital infections), can maintain themselves for prolonged periods in environments such as waterbodies, forming contamination pathways. These microbes are common in the intestinal microbiota and can, in certain situations of lowered immunity of the human organism, cause endogenous and exogenous (skin or mucosa colonization) infections. Because of their opportunistic character they are known as amphibionts (23).

Samples were collected in Cabiúnas, Imboassica, and Geribá coastal lagoons, located on the northeastern coastal plain of the state of Rio de Janeiro. The occurrence of GNBs showing phenotypical resistance markers (expression of genes specific for resistance and/or manifestation of constitutive resistance) to therapeutic or prophylactic antimicrobials used to treat human infections (also used in veterinary treatments and the food industry) was evaluated. We also collected samples from the sewage drain of the Pedro Ernestro University Hospital, qualitatively evaluating microorganisms discharged into the extra-hospital environment.

The objectives of this study were: I) To examine the possibility of relationships between poor sanitation (indicated by the presence of fecal coliforms) and ecological degradation (defined by nutrient concentrations) and the phenotypes of bacterial resistance found in the environments analyzed; II) To propose a general model of circulation of bacterial resistance, suggesting the means of interaction among the waterbodies, certain habitats that are strongly selective for antimicrobialresistant bacteria, and the general community environment.

\section{MATERIALS AND METHODS}

\section{Study Area}

Geribá Lagoon is located in Búzios in the municipality of Cabo Frio, Rio de Janeiro. When it was sampled, the lagoon had a mean depth of 10 to $20 \mathrm{~cm}$. The drainage canal, which carries the domestic waste of approximately 4,000 people, is slightly higher than the lagoon surface and its contents cannot be diluted by lagoon water. This lagoon is in a state of advanced eutrophication and sanitary degradation.

Imboassica and Cabiúnas lagoons are located in the municipalities of Macaé and Carapebus, Rio de Janeiro. These lagoons have mean depths of 1.5 and $3.2 \mathrm{~m}$, and areas of 3.26 and $0.34 \mathrm{~km}^{2}$ respectively (26). Cabiúnas Lagoon lies within the Restinga de Jurubatiba National Park, and receives no waste input. Imboassica Lagoon receives the domestic waste of approximately 10,000 persons and is undergoing artificial eutrophication (10). Its canal is relatively wide (5 to $7 \mathrm{~m}$ ) and lies at the same level as the lagoon, allowing the lagoon water to enter and dilute the effluents. The wastes discharged into Imboassica and Geribá lagoons do not include hospital effluents.

HUPE-UERJ University Hospital is a third-level 600-bed public hospital located in the municipality Rio de Janeiro city. It is an important treatment center for ambulatory, clinical and surgical inpatients from this and surrounding municipalities.

\section{Determination of Environmental Parameters}

The concentrations of total nitrogen $(\mathrm{N})$ were determined according to Mackereth et al. (21) and phosphorus (P) using the method proposed by Golterman et al. (13). The values for salinity were obtained by means of a LabComp salinometer and for colimetry by the methods proposed by Apha (1). The environmental parameters of the hospital effluent were not determined.

\section{Detection of Microorganisms and Resistance Markers}

Lagoon samples - For the bacterial cultures we used Escherichia coli (EC) broth (Merck) in $100 \mathrm{ml}$ volumes, concentrated $2 \mathrm{x}$, containing Cephalothin for a final concentration of $32 \mu \mathrm{g} / \mathrm{ml}$. Cephalothin resistance, which has significant clinical importance, is frequently found in situations without strongly selectivity (water reservoirs and non-hospitalar strains in general), having high association with other markers as Chloramphenicol, Tetracycline and Trimethoprimsulfamethoxazole, considered in our categorization as "common" markers (see text below). This allowed addition of a sample volume of $100 \mathrm{ml}$.

Sample from hospital drain - For the bacterial cultures we used EC broth in $100 \mathrm{ml}$ volumes, concentrated 2x, containing Gentamicin for a final concentration of $8 \mu \mathrm{g} / \mathrm{ml}$. Due to the high correlation between Gentamicin resistance and multirresistant profiles in hospitalar strains (34), this antimicrobial was used as a selective agent to eliminate a high number of strains with no importance to our objectives. This allowed addition of a sample volume of $100 \mathrm{ml}$.

Cultures - Inoculated media were incubated at $37^{\circ} \mathrm{C}$ for $24-$ 48 hours. Subsequently, about $5 \mu \mathrm{l}$ of the EC broth culture was seeded by decanting onto Eosin Methylene Blue agar (EMB) 
containing $32 \mu \mathrm{l} / \mathrm{ml}$ of Cephalothin. These cultures were incubated at $37^{\circ} \mathrm{C}$ for 24 hours.

Bacterial identification and tests of sensitivity to the antimicrobials - Bacterial identification was based on colony morphology in culture medium, bacterioscopy of Gram-stained bacterial streaks, standard oxidation-fermentation (HughLeifson), oxidase production, glucose and lactose fermentation, urease activity, $\mathrm{H}_{2} \mathrm{~S}$ production (from sulfur-containing amino acids), indole from tryptophan, use of citrate and malonate and decarboxylation of lysine, arginine and ornithine (9). The bacterial strains were tested by Muller Hinton agar diffusion for sensitivity to a group of antimicrobials: Cephalotin, Cefoxitin, Cefotaxime, Ceftazidime, Tetracycline, Chloramphenicol, Trimethoprim-sulphamethoxazole, Gentamicin, Amikacin, and Norfloxacin according to Bauer et al. (4). Two strains of the same species were considered distinct if they showed different patterns of resistance to the antimicrobials.

Categorization of the antimicrobials - In order to evaluate the degrees of bacterial and antimicrobial resistance, based on the specialized literature (32), we established a priori categories of antimicrobials use, for practicality in obtaining indications of bacterial selection. A) Those antimicrobials considered as "common" (frequent use in community) as Chloramphenicol, Tetracycline, Trimethoprim-sulfamethoxazole (chemotherapeutic agent), Cephalothin (also used in hospitals) and Cefoxitin; B) "Special" antimicrobials (Primarily hospital use/ more restrict use) as Cefotaxime, Ceftazidime, Imipenem/Meropenem, Norfloxacin (chemotherapeutic agent), Amikacin and Gentamicin.

Based in this antimicrobial categories we determined three categories of strains according to the type of resistance marker or markers detected: strongly "multi-resistant" (expression of resistance to more than two groups of special antimicrobials); "sensitive" (slightly resistant: few markers showing associations of common markers, frequently encountered in bacterial agents of community or ambulatory infections), and a third, "intermediate" group of bacteria, carrying up to two markers for resistance to antimicrobials, which are indicators of stronger selection processes (hospital, clinics, cattle raising, food industry, etc.).

\section{RESULTS}

At the outlet of the Geribá Lagoon sewage canal we measured high total $\mathrm{P}$ and $\mathrm{N}$ contents, and a high coliform count. In the limnetic zone, the total $\mathrm{N}$ and $\mathrm{P}$ contents were respectively 82.5 and $75.6 \%$ lower than in the sewage canal. The number of total coliforms in the limnetic zone was more than 1000X smaller than sewage canal number, and the fecal coliform density was 900,000 in the sewage canal and $<2 \mathrm{MPN} / 100 \mathrm{ml}$ in the limnetic zone. The salinity in limnnetic zone was 10X higher than that found to sewage canal (Table 1).

High total phosphorus and nitrogen contents were found in the Imboassica Lagoon sewage canal, although all values were lower than those found in the Geribá canal. In the Imboassica Lagoon limnetic zone, the total $\mathrm{N}$ and $\mathrm{P}$ concentrations were respectively 76.8 and $88.6 \%$ lower than in the sewage canal. The MPN/100 ml of fecal and total coliforms were similar in the Geribá and Imboassica canals, although in the limnetic zone of Geribá there was substantially higher reduction in relation to the sewage canal than in Imboassica (Table 1). The total nitrogen and phosphorus contents were markedly lower in Cabiúnas Lagoon, as were the estimates for total and fecal coliforms (Table 1).

For all samples, except that from the limnetic zone of Geribá Lagoon, we were able to isolate in the selective media, bacterial colonies belonging to species or genera of GNBs that are important in human infections, with a potential to transfer resistance to other bacteria (Table 2). The general categories of microorganisms found in the Geribá sewage canal were fecal coliforms (E. coli), non-fecal coliforms (Enterobacter, Citrobacter, and Klebsiella), and non-fermenting GNBs (e.g., Acinetobacter sp. and the genus Aeromonas).

In the Geribá canal, the presence of the Ceftazidime- and Norfloxacin-resistant E. coli, Amikacin- and Gentamicinresistant $K$. pneumoniae, and Ceftazidime-resistant $C$. freundii strains established the occurrence of intermediate bacterial resistance at that location. The other strains analyzed, except for the hospital strains, which were all multi-resistant, showed a low resistance profile ("sensitive" strains).

Table 1. Total Nitrogen, total phosphorus, salinity, $\mathrm{pH}$ and MPN of total and fecal coliforms at the three lagoons sampled.

\begin{tabular}{cccccccc}
\hline Lagoon & $\begin{array}{c}\text { Sampling } \\
\text { Location }\end{array}$ & $\begin{array}{c}\text { Total Nitrogen } \\
(\mu \mathrm{g} / \mathrm{l})\end{array}$ & $\begin{array}{c}\text { Total Phosphorus } \\
(\mu \mathrm{g} / \mathrm{l})\end{array}$ & $\begin{array}{c}\text { Total Coliforms } \\
(\mathrm{MPN} / 100 \mathrm{ml})\end{array}$ & $\begin{array}{c}\text { Fecal Coliforms } \\
(\mathrm{MPN} / 100 \mathrm{ml})\end{array}$ & Salinity & $\mathrm{pH}$ \\
\hline Geribá & Sewage outlet & $13,340.9$ & $2,817.9$ & $>1,600,000$ & 900,000 & 3.2 & 7.63 \\
& Limnetic zone & $2,325.5$ & 685.1 & 900 & $<2$ & 34.1 & 8.58 \\
Imboassica & Sewage outlet & $10,103.7^{* *}$ & $1,058.7^{* *}$ & $>1,600,000$ & 900,000 & 4.28 & 7.58 \\
& Limnetic zone & $2,340.38^{*}$ & $120.64^{*}$ & 240,000 & 4 & 4.32 & 7.99 \\
Cabiúnas*** & & 709.38 & 15.36 & 1,200 & $<2$ & 0.5 & 6.7 \\
\hline
\end{tabular}

* Means of data from March 1999 through June 2002 (source: UFRJ Limnology Laboratory);

** Taken from Lopes-Ferreira (1998);

*** Means of data from March 1999 through June 2002 (source: UFRJ Limnology Laboratory). 
Table 2. Microorganisms isolated in media selective for enterobacteria and non-fermenting Gram-negative bacilli (containing 32 $\mu \mathrm{g} / \mathrm{ml}$ cephalothin), present in samples taken during the year 2000 from 3 coastal lagoons of the state of Rio de Janeiro and the drain of the HUPE-UERJ University Hospital, Rio de Janeiro.

\begin{tabular}{|c|c|c|c|}
\hline Site & Microorganisms & Resistance Markers* & Category** \\
\hline $\begin{array}{l}\text { Geribá } \\
\text { Lagoon }\end{array}$ & $\begin{array}{l}\text { 1. DRAINAGE CANAL OUTLET } \\
\text { Klebsiella pneumoniae } \\
\text { Escherichia coli } \\
\text { Enterobacter cloacae } \\
\text { Citrobacter freundii } \\
\text { Aeromonas sp } \\
\text { GNNFB*** } \\
\text { 2. LIMNETIC ZONE } \\
\text { Negative Culture }\end{array}$ & $\begin{array}{l}\mathrm{Ce} \mathrm{Am} \mathrm{Gm} \\
\mathrm{Cl} \mathrm{Te} \mathrm{Ts} \mathrm{Ce} \mathrm{Cz} \mathrm{Nr} \\
\mathrm{Ce} \mathrm{Co} \\
\mathrm{Ce} \mathrm{Co} \mathrm{Cz} \mathrm{Te} \\
\text { Ts Ce } \\
\mathrm{Cl} \mathrm{Te} \mathrm{Ts} \mathrm{Ce} \mathrm{Co}\end{array}$ & $\begin{array}{l}\mathrm{I} \\
\mathrm{I} \\
\mathrm{S} \\
\mathrm{I} \\
\mathrm{S} \\
\mathrm{S}\end{array}$ \\
\hline $\begin{array}{l}\text { Cabiúnas } \\
\text { Lagoon }\end{array}$ & $\begin{array}{l}\text { GNNFB } \\
\text { Enterobacter cloacae } \\
\text { Serratia marcescens }\end{array}$ & $\begin{array}{l}\mathrm{Cl} \mathrm{Te} \mathrm{Ce} \mathrm{Co} \\
\mathrm{Te} \mathrm{Ce} \mathrm{Co} \\
\mathrm{Te} \mathrm{Ce} \mathrm{Co}\end{array}$ & $\begin{array}{l}\mathrm{S} \\
\mathrm{S} \\
\mathrm{S}\end{array}$ \\
\hline $\begin{array}{c}\text { Imboassica } \\
\text { Lagoon }\end{array}$ & $\begin{array}{l}\text { 1. SEWAGE CANAL OUTLET } \\
\text { GNNFB } \\
\text { Citrobacter sp. } \\
\text { Enterobacter cloacae } \\
\text { 2. LIMNETIC ZONE } \\
\text { Escherichia coli }\end{array}$ & $\begin{array}{l}\mathrm{Ce} \mathrm{Co} \\
\mathrm{Ce} \mathrm{Co} \mathrm{Te} \\
\mathrm{Te} \mathrm{Ce} \mathrm{Co} \\
\mathrm{Ce} \mathrm{Co}\end{array}$ & $\begin{array}{l}\mathrm{S} \\
\mathrm{S} \\
\mathrm{S}\end{array}$ \\
\hline HUPE**** & $\begin{array}{l}\text { Klebsiella pneumoniae } \\
\text { Klebsiella pnemoniae } \\
\text { Klebsiella oxytoca } \\
\text { klebsiella oxytoca } \\
\text { Citrobacter freundii } \\
\text { Acinetobacter calcoaceticus }\end{array}$ & $\begin{array}{l}\text { Te Ts Ce Co Cz Cx Nr Am Gm } \\
\text { Cl Te Ce Co Cz Im Nr Am Gm } \\
\text { Cl Te Ce Co Cz Cx Nr Am Gm } \\
\text { Cl Te Ce Cz Cx Nr Am Gm } \\
\text { Te Ts Ce Co Cz Im Nr Am Gm } \\
\text { Cl Te Ts Ce Co Cz Cx Im Nr Am Gm }\end{array}$ & $\begin{array}{l}\text { MR } \\
\text { MR } \\
\text { MR } \\
\text { MR } \\
\text { MR } \\
\text { MR }\end{array}$ \\
\hline
\end{tabular}

$* \mathrm{Cl}=$ Chloramphenicol, $\mathrm{Te}=$ Tetracycline, $\mathrm{Ts}=$ Trimethoprim-sulfamethoxazole, $\mathrm{Ce}=$ Cephalosporin, $\mathrm{Co}=\mathrm{Cefoxitin}, \mathrm{Cz}=\mathrm{Ceftazidime}$, $\mathrm{Cx}=$ Cefotaxime, $\mathrm{Im}=$ Imipenem, $\mathrm{Nr}=$ Norfloxacin, $\mathrm{Am}=$ Amikacin, $\mathrm{Gm}=$ Gentamicin. $* * \mathrm{MR}=$ multi-resistant (high selection), $\mathrm{I}=$ intermediate (special markers present indicating previous selection); $\mathrm{S}=$ "sensitive" ("common" resistance markers). *** GNNGFB $=$ Gram-negative non-glycose fermenting bacillus. **** Sample from hospital drain isolated in selective medium containing 8 의 ml Gentamicin.

\section{DISCUSSION}

The relatively high total phosphorus and nitrogen contents in Geribá Lagoon indicate its advanced stage of artificial eutrophication, while the densities of fecal coliforms demonstrate the deterioration in sanitary conditions in the lagoon. As previously mentioned, this lagoon has a small water volume and is located in a region of low rainfall, limiting the capacity for dilution of effluents and thus contributing to the acute eutrophication. In the limnetic zone there were marked reductions in the densities of fecal coliforms, and no bacterial strains were isolated that were resistant to the antimicrobials considered in this study. The high salinity in the limnetic zone, in contrast to the low salinity of the effluent input, may account for the absence of resistance strains and the low density of fecal coliforms, besides contributing to the high $\mathrm{pH}$ value.
In the Geribá Lagoon sewage canal, bacterial strains showing markers for resistance to special-type antimicrobials were present (Table 2). Although these markers for intermediate resistance do not indicate a strong previous selection, as do the markers for the hospital strains, their presence suggests that moderate selection has occurred, possibly originating in the activities of hospitals or local clinics. In line with this interpretation is the fact that this lagoon does not receive non-domestic effluents. This kind of resistance profile may originate in individuals who were recently hospitalized, or may indicate the degree of selection exerted by the use of antibiotics in a community setting. Touching on the first hypothesis, it is important to consider that, according to Vecina-Neto (33), there is a mean of 13.3 hospitalizations per 100 inhabitants per year in Brazil, which suggests a close connection between the hospital and community 
environments. On the other hand, the use of antimicrobials in the domestic setting has expanded and may be exercising enough selection pressure to permit the appearance of moderate resistance profiles, thus confirming the increase in the problem of resistance in the community (2).

The resistance markers observed in Cabiúnas and Imboassica lagoons are common, and do not indicate the presence of considerable previous selection. Slightly resistant strains, indicating low levels of selection, may be found equally in locales where there is no discharge of organic effluents, and in situations of compromised sanitation. This emphasizes the importance of the selection process in determining critical and moderate resistance profiles, demonstrating a lack of connection between the scenarios of sanitary and ecological degradation, and the resistance profiles found. Sherley et al. (29) observed resistance to 32 therapeutic antimicrobials in strains of enterobacteria isolated from wild animals in Australia. In the same study, resistance to Amikacin, Ciprofloxacin, Meropenem, and Gentamicin was found in none of the strains analyzed (these four antibiotics are listed as "Special"). Papandreou et al. (24) described a high frequency of resistance to Cephalothin, Ampicillin, Carbenicillin, Cefuroxime, and Cefoxitin in Gram-negative bacterial strains isolated from the Patras Reservoir in southwestern Greece. Of these antibiotics, all can be considered "common" according to the categories used in this study. In the same study, the 239 strains isolated were sensitive to quinolones, aminoglycosides, Imipenem, Aztreonam, Ceftazidime, and Cefoperazone; all these compounds and groups of compounds were considered "special" in this study.

Strains resistant to antimicrobials may, under certain conditions, transfer genes by means of plasmids (19) to other strains that are resistant to other antibiotics, and this process can generate strains resistant to a larger group of antibiotics than formerly. Plasmids (self-replicating DNA molecules), which in many situations can carry genes for resistance to antimicrobials $(5,15)$, are potentially transferable among bacteria (31). In these plasmids there may be veritable "blocks" of genes, determining the expression of multiple resistance $(5,30)$. Transposons are highly important in increasing the mobility of different genes favoring the acquisition of resistance genes by plasmids, the latter originating in the chromosomes and/or in other plasmids (7). As this process continues, multi-resistant strains are generated, leading to additional problems in the treatment of infections caused by them. The increase in connectivity (dispersal of resistance genes) among the compartments shown in Fig. 1, just as among the elements resident in each compartment, potentially contributes to the occurrence of gene transfers. Gene transfers associated with selection pressures are responsible for the appearance of multiresistance profiles (8), and is also of fundamental importance for dispersion of resistance genes (2).

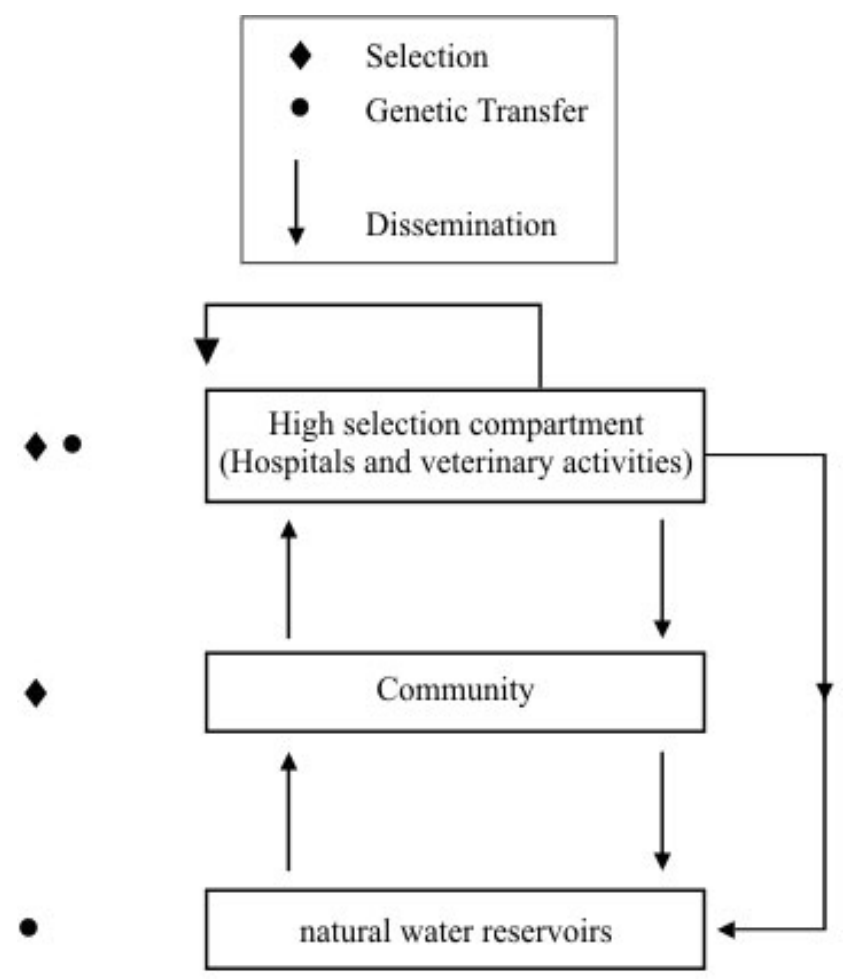

Figure 1. Resistant strains cycling model by the three proposed compartments considering selection, genetic transfer and dissemination processes.

The "high selection" compartment considered in Fig. 1, which includes hospitals and veterinary activities, merits emphasis regarding the transfer of resistance genes among its constituent elements (hospitalized patients or animals given large doses of different antibiotics for long periods). The dissemination of resistant strains has been studied in hospitals, and has been indicated as a source of serious problems relative to infections in hospitals (11). Great efforts have been made in hospitals worldwide to avoid contamination of patients by multiresistant bacterial strains, which aggravate the clinical picture of infections, increasing morbidity and mortality (12).

It is a well-known concept that resistance genes (and correspondingly, markers for resistance to antimicrobials) appear, except in the case of special selective conditions, randomly in bacteria as do those of isolated genera and species. Groups of genes (and the markers for resistance to antimicrobials) would by this hypothesis appear in a random manner. But, in environments with active selection by antimicrobials, the associations among genes (and subsequently among phenotypic markers for resistance) would occur in a statistically dependent manner, thus increasing the association frequencies of resistance genes (and of phenotypic markers), which in the context of random associations, would 
be relatively rare $(25,27,28)$. Among the strains obtained in our study, those isolated from the hospital drain are examples of associations of resistance markers that are indicators of strong selection.

Within the "community" compartment, there is the potential for high frequency of transfer of resistance in situations of poor sanitation in houses and, principally, by means of contaminated bodies of water. It is noteworthy that in localities with few resources and especially poor sanitation, due caution with hospital effluents is not observed, and these are often discharged completely untreated into waterbodies. Guardabassi et al. (14) showed that the use of an antimicrobial, oxolinic acid, in trout feed could alter the resistance profile of bacteria isolated from streams downstream from the point of discharge of the effluents. Thus, waterbodies receiving effluents containing strongly selected bacteria can constitute an important genetic route for transfer of multi-resistance among the high-selection compartments and the general community. A well-described process of interaction among the compartments under consideration resulted from the intensive veterinary use of a peptidic antibiotic, Avoparcin, which lead to establishment of resistance of enterococci to Vancomycin $(3,18)$. Casual transfer of this determinant of resistance can have serious consequences for the treatment of one of the most important human pathogens, Staphylococcus aureus, for which, after wide resistance developed, Vancomycin was held to be the last resource for treatment (6).

In this study, we focused our efforts on enterobacteria, particularly on coliforms (this is the reason for the use of EC media), but we recognize the importance of other fecal indicators like Enterococci and Clostridium, that we intend to approach in future studies. The purpose of the present study was to demonstrate the importance of considering the entire system in treating the question of bacterial resistance. Cycling of resistant strains plays a fundamental role in the appearance of profiles of multi-resistance. Treating the question of bacterial resistance to antibiotics in the global context requires not only adequate knowledge of cellular and molecular mechanisms, but increasingly demands ecological and epidemiological approaches (2). It is necessary to invest in new medications and in improved sanitation of communities and waterbodies, and through research to develop functional predictive models. These models must arise from interdisciplinary research groups that are able to take into account molecular, clinical, socioeconomic, epidemiological, and ecological aspects of the problem.

\section{ACKNOWLEDGMENTS}

The authors gratefully acknowledge to CNPq and Petrobras for financial support, to Ambiotec S.A. and to Dr. Jorge Cerpin from HUPE-UERJ for technical support.

\section{RESUMO}

\section{Aspectos ecológicos da resistência antimicrobiana de bactérias de importância em infecção humana}

Tendo em vista a íntima relação entre os seres humanos e as lagoas costeiras (usadas para recreação, turismo, fornecimento de água, etc.), o lançamento de efluentes domésticos e hospitalares podem contribuir para o estabelecimento de rotas de disseminação de microorganismos patogênicos, incluindo aqueles carreadores de genes de resistência a antimicrobianos. O objetivo da presente investigação foi o de relacionar a presença de bactérias resistentes a antimicrobianos com características ambientais de três lagoas costeiras, comparando os resultados com os obtidos em esgoto hospitalar. Das lagoas estudadas, duas (Geribá e Imboassica) recebem efluentes domésticos e outra (Cabiúnas), se encontra em estado natural. Utilizando cultura contendo 32 $\mu \mathrm{g} / \mathrm{ml}$ de Cefalotina, isolamos coliformes fecais (E. coli), coliformes não-fecais (Klebsiella, Enterobacter, Serratia e Citrobacter), bacilos gram-negativos não fermentadores de glicose e Aeromonas sp. Nas culturas de esgoto hospitalar foram isoladas cepas contendo marcadores de resistência para a maioria dos 11 antibióticos testados. No outro extremo, foram isoladas apenas cepas apresentando resistências a antibióticos freqüentemente observadas em situações não-seletivas (considerados aqui como marcadores "comuns") nas lagoas Cabiúnas e Imboassica. A capacidade de diluição do corpo aquático e a salinidade mostraram-se relacionados com a ocorrência de cepas multirresistentes, enquanto a intensidade de contaminação fecal recente não se mostrou associada ao número e tipos de marcadores detectados.

Palavras-chave: resistência bacteriana, eutrofização, microbiologia sanitária, microbiologia ambiental.

\section{REFERENCES}

1. Apha. Stardard methods for the examination of water and wastewater. Washington: Am. Public Health Assoc., 1985. 1268p.

2. Baquero, F.; Negri, M.C.; Morosini, M.I.; Blázquez, J. The antibiotic selective process: concentration-specific amplification of low-level resistant populations. Ciba Found Symp., 207: 93105, 1997.

3. Bates, J.; Jordens, Z.; Selkon, J.B. Evidence for animal origin of vancomycin-resistant enterococci. Lancet, 342: 490-491,1993.

4. Bauer, A.W.; Kirby, W.M.M.; Sherris, J.C.; Turk, M. Antibiotics susceptibility testing by a standardized single disk method. Am. J. Clin. Pathol., 45: 493-496, 1966.

5. Broda, P. Plasmids. W.H. Oxford: Freeman and Company, 1979.

6. Cormican, M.G.; Erwin, M.E.; Jones, R.N. Avoparcin a glycopeptide used in animal foods: antimicrobial spectrum and potency tested against human isolates from the United States. Diagn. Microbiol. Infect. Dis., 29: 241-248, 1997.

7. Dale, J.W. Molecular genetics of bacteria. John Wiley \& Sons Ltd. $3^{\text {rd }}$ ed. 1998 . p. 130

8. Davison, J. Genetic exchange between bacteria in the environment Plasmid 42:73-91, 1999. 
9. Edwards, P.R.; Ewing, H.W. Identification of Enterobacteriaceae. $3^{\text {rd }}$ ed. Minneapolis: Burgess Publishing Co., 1972

10. Esteves, F.A. ed. Ecologia das Lagoas Costeiras do Parque Nacional da Restinga de Jurubatiba e do Município de Macaé (RJ), Rio de Janeiro, 1998

11. French, G.L.; Phillips, I. Antimicrobial resistance in hospital flora and nosocomial infections. In: Mayhall C.B. et al. eds. Hospital Epidemiology and Infection Control., Baltimore: Willims \& Wilkins, 1996: 980-999.

12. Goldmann, D.A.; Huskins, C. Control of nosocomial antimicrobialresistant bacteria: a strategy for hospitals wordwide. Clin. Infect. Dis., 24 (suppl 1): S139-S145, 1997.

13. Golterman, H.L.; Clyo, R.S.; Ohnstad, M.A.M. 1978. Methods for physical and chemical analysis of freshwater., Blackwell Scientific Publ., Oxford, 214p.

14. Guardabassi, L.; Dalsgaard, A.; Raffatellu, M.; Olsen, J.E. Increase in the prevalence of oxolinic acid resistant Acinetobacter spp. Observed in a stream receiving the effluent from a freshwater trout farm following thetreatment with oxolinic acid-medicated feed. Aquaculture, 188: 205-218, 2000.

15. Hardy, K.G. (ed.) Plasmids. A practical approach. IRL Press, Oxford, 1987.

16. Harihan, R.; Weinstein, R.A. Enterobacteriaceae. In Mayhall, C.G. (ed.) Hospital epidemiology and infection control. Williams \& Wilkins, Baltimore. 1996. P.345-366.

17. Jacoby, G.A.; Archer, G.L. New mechanisms of bacterial resistance to antimicrobial agents. N. Engl. J. Med., 324: 60

18. Klein, G.; Pack, A.; Reuter,G. Antibiotic resistance patterns of enterococci and occurrence of vancomycin-resistant enterococci in raw minced beef and porck in Germany. Appl. Environ. Microbiol., 64: $1825-1830,1998$

19. Linton, A.H. Flow of resistance genes in the environment and from animals to man. J. Antimicrob. Chemother., 18 [suppl. C.]: 189-97, 1986.

20. Lopes-Ferreira, C. Redução das concentrações de Nitrogênio e Fósforo dos efluentes domésticos lançados na lagoa Imboassica, através de uma região colonizada por macrófitas aquáticas. In: Esteves, F.A. ed., Ecologia das Lagoas Costeiras do Parque Nacional da Restinga de Jurubatiba e do Município de Macaé (RJ). 1998.

21. Mackereth, F.J.H.; Heron, J.; Talling, J.F. 1978. Water analisis: some revised methods for limnologists. Freshwater Biological Association, scientific publication $\mathrm{n}^{\circ} 36$, Cumbria and Dorset, 1978.

22. Mayhall, C.G. Hospital epidemiology and infection control. $3^{\text {rd }}$. ed. Baltimore, Williams \& Wilkins, 1996.
23. Mendonça-Hagler, L.C.; Hagler, A.N. Microbiologia aquática. In: Roitman, I. et al. (eds.) Tratado de Microbiologia vol. II. Microbiologia Ambiental. Ed. Manole, 1991.

24. Papandreou, S.; Pagonopoulou, O.; Vantarakis, A.; Papapetropoulou, M. Multiantibiotic resistance of Gram-negative bacteria isolated from drinking water samples in southwest Greece. J. Chemother, 12: 26773, 2000.

25. Pereira, J.A.A. Estudo epidemiológico da infecção hospitalar e resistência a antimicrobianos e ao telurito em Enterobacteriaceae com referência especial a Klebsiella pneumoniae. Tese de doutoramento. Instituto de Microbiologia, UFRJ, 1990.

26. Petrucio, M.M. Caracterização das lagoas Imboassica, Cabiúnas, Comprida e Carapebus a partir da Temperatura, Salinidade, Condutividade, Alcalinidade, $\mathrm{O}_{2}$ Dissolvido, $\mathrm{pH}$, Transparência e Material em suspensão. In: Esteves, F.A. ed., Ecologia das Lagoas Costeiras do Parque Nacional da Restinga de Jurubatiba e do Município de Macaé (RJ). 1998.

27. Ponce-de-Leon, A.C.; Pereira, J.A.A. A distribuição binomial truncada como modelo para explicar padrões de resistência a antimicrobianos. 13a SINAP - Simpósio Nacional de Probabilidade e Estatística, Resumos, Caxambu, 1998.

28. Ponce-de-Leon, A.C.; Sampaio, L.O.B.; Castro, E.A.R.; Melo, S.A.C.; Queiroz, M.L.F.; Suassuna, I.; Pereira, J.A.A. Padrões de resistência a antimicrobianos: uma comparação entre os ambientes nosocomial e comunitário. II Congresso Pan-Americano (VII Brasileiro) de Controle de Infecções e Epidemiologia Hospitalar, Belo Horizonte, MG. 2000. p. 170.

29. Sherley, M.; Gordon, D.M.; Collingnon, P.J. Variations in antibiotic resistance profile in Enterobacteriaceae isolated from wild Australian animals. Environ. Microbiol. 2 6: 620-31, 2000.

30. Silver, L.L.; Bostian, K.A. Discovery and development of new antibiotics: the problem of antibiotic resistance. Antimicrob. Agents Chemother, 37: 377-383, 1993.

31. Sonea, S. The global organism. The Sciences. July-August. 1988. p. $38-45$.

32. Tavares, W. Manual de antibióticos e quimioterápicos. Atheneu, São Paulo, 1996.

33. Vecina-Neto, G. Evolução e perspectivas da assistência à saúde no Brasil. In: Fernandes, A.T. (ed.). Infecção hospitalar e suas interfaces na área da saúde. Atheneu, São Paulo. 2000. Pg. 1613-1617.

34. Vieira, L.A.; Castro, E.A R.; Duarte, J.L.B.; Pinheiro, S.R.; Suassuna, I.; Pereira, J.A.A. Colonização intestinal de recém-natos por enterobactérias multirresistentes a antimicrobianos em unidade neonatal. J. Pediatria, 75(2): 83-90, 1999. 
Brazilian Journal of Microbiology (2002) 33:287-293

ISSN 1517-8382287

ECOLOGICAL ASPECTS OF THE ANTIMICROBIAL RESISTANCE IN BACTERIA OF IMPORTANCE TO HUMAN INFECTIONS

Frederico de Meirelles-Pereira ${ }^{*}$; Angela de Meirelles Santos Pereira ${ }^{2}$; Márcio Cataldo Gomes da Silva ${ }^{3}$; Verônica Dias Gonçalves3; Paulo Roberto Brum¹; Eduardo Almeida Ribeiro de Castro2; Alexandre Adler Pereira ${ }^{3}$; Francisco de Assis Esteves ${ }^{1}$; José Augusto Adler Pereira ${ }^{3}$

${ }^{1}$ Laboratório de Limnologia, Departamento de Ecologia, Instituto de Biologia, Centro de Ciências da Saúde, Universidade Federal do Rio de Janeiro, Rio de Janeiro, RJ, Brasil.

2 Departamento de Patologia e Laboratórios, Faculdade de Ciências Médicas, Universidade Estadual do Rio de Janeiro, Rio de Janeiro, RJ, Brasil.

${ }^{3}$ Hospital Universitário Pedro Ernesto, Universidade Estadual do Rio de Janeiro, Rio de Janeiro, RJ, Brasil.

Submitted: November 13, 2001; Returned to authors for corrections: June 17, 2002; Approved: September 03, 2002 
The correct figure and respective caption are presented below (the original caption contains the word "tranfer", being the correct expression "transfer"):

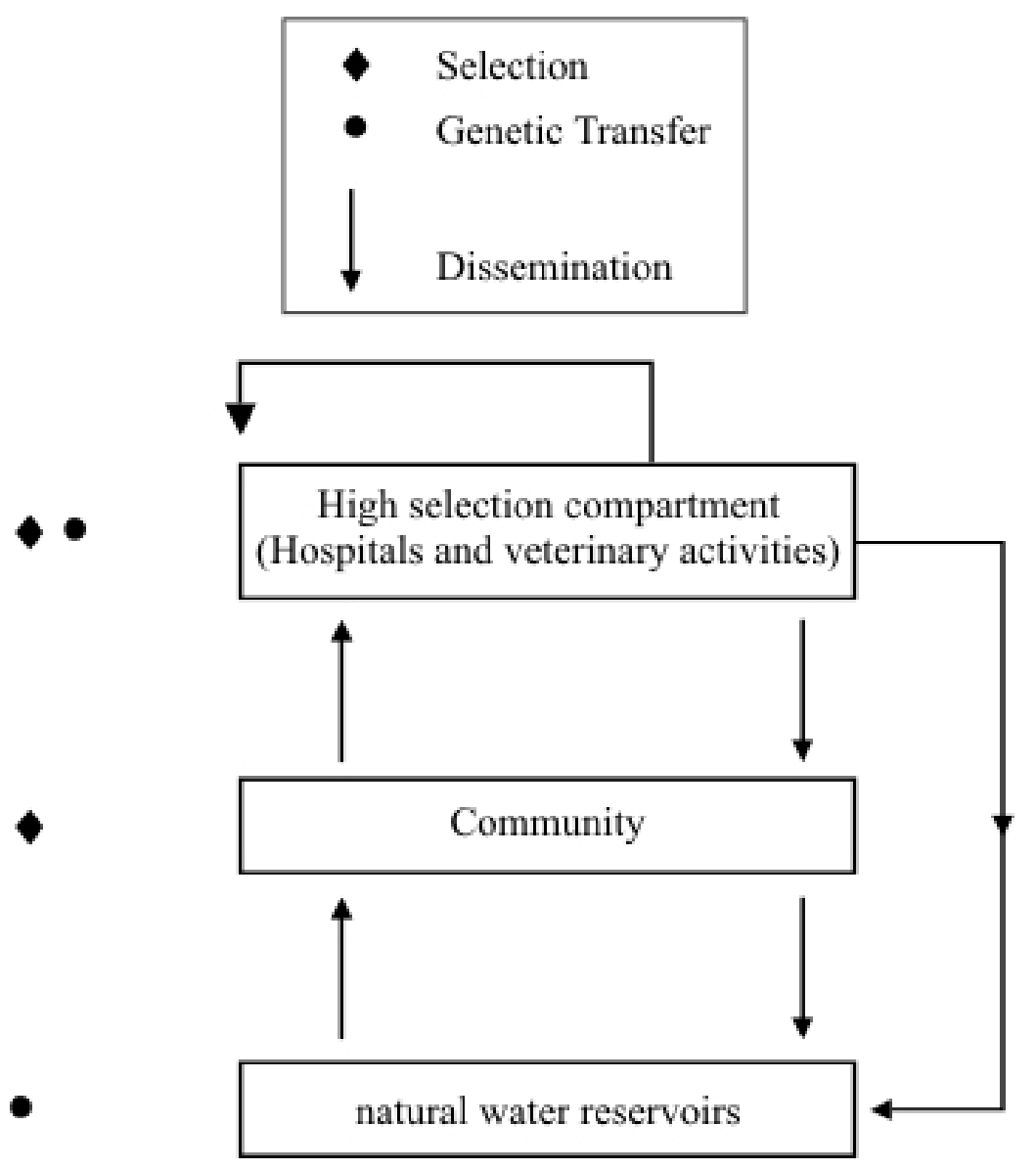

\section{Figure 1.}

\section{Caption:}

Resistant strains cycling model by the three proposed compartments considering selection, genetic transfer and dissemination processes. 